\title{
FLORAL BIODIVERSITY OF THE SETI GANDAKI RIVER, POKHARA NEPAL: PHYTOPLANKTON COMMUNITIES
}

\author{
K.K. Pokharel
}

\section{ABSTRACT}

Present paper deals with the phytoplankton communities in the Seti Gandaki river, Pokhara, Nepal. It is the pioneer work to explore the above mentioned riverine flora. Altogether 28 genera belonging to 19 families and 5 classes were recorded during the investigation period. There was a decrease in taxa richness from upstream site (19 genera) to the urban site (9 genera) and an increasing trend to the downstream site (15 genera).

Myxophyceae, bacillariophyceae and chlorophyceae comprising 10, 9 and 6 genera respectively were predominant classes among the phytoplankton communities. Oscillatoriaceae and nostocaceae; fragilariaceae and achnanthaceae; and zygnemataceae were dominant families among myxophyceae, bacillariophyceae and chlorophyceae respectively. The dominant genera were, Microcystis Kutzing, Oscillatoria Vaucher and Anabaena Bory; Tabellaria Ehrenberg, Achnanthes Bory and Cymbella Agardh; Ulothrix Kutzing and Spirogyra Link; and Peridinium Ehrenberg among myxophyceae, bacillariophyceae, chlorophyceae and dinophyceae respectively. The genera found at all sites were, Tabellaria Ehrenberg, Achnanthes Bory and Cymbella Agardh; and Microcystis Kutzing, Anabaena Bory, Oscillatoria Vaucher and Schizothrix Kutzing among bacillariophyceae and myxophyceae, where as, those occurred only at Site 2 were, Chlamydomonas Ehrenberg, Oedogonium Link, Scenedesmus Meyen and Zygnema Agardh; Euglena Ehrenberg; Fragilaria Lyngbye; Gymnodinium Stein; and Merismopedia Meyne among chlorophyceae, euglinophyceae, bacillariophyceae, dinophyceae and myxophyceae respectively.

The decline in taxa richness at the urban site reflects the perturbation of the riverine environment due to urbanization which needs regular monitoring and essential measures to control further deterioration.

Key Words: phytoplankton, floral biodiversity, distribution, Seti Gandaki river, Nepal

\section{INTRODUCTION}

The small organisms or microorganisms physiologically similar to the plants remaining suspended and passively drifting in and getting nutrients from the water constitute the phytoplankton. These are essential components having photosynthetic ability upon which depends the rest of the biological community.

Earlier limnologists/phycologists mentioned that, the true plankters are temporary inhabitants brought to the streams or rivers from still waters (Welch 1952, Ruttner 1956, Cushing 1964), others are found representatives of benthic algal cells-mostly diatoms, washed up or displaced from the benthos or stream-bed in headwater streams, from side-arms or back-water areas, from submerged vegetation along the banks (Hynes 1970, Reynolds and Descy 1996, Allan1995), others observed the presence of plankton in downstream drift in small streams 
due to seasonal spates and level of water (Blum 1954, Muller-Haeckel 1966); some others mentioned predominating true plankters in larger rivers which may be reduced by turbidity (Whitton 1975, Reynolds et al. 1994). Generally river phytoplankton or potamoplankton grow faster and are smaller in size than those of lakes and reservoirs. Their survival is ensured particularly by backwater areas, which retain water for additional cell divisions (Soballe and Kimmel 1987, Wetzel 2001).

Studies on phytoplankton diversity by several earlier limnologists / phycologists observed planktonic community in lotic waters (Lauterborn 1902, Brehm 1911, Chakraborty et al. 1959, Ruttner 1963). Some works on phytoplankton have been performed in waterbodies situated in different parts of Nepal (Hirano 1955, Kusel-Fetzmann 1969, Joshi 1977, Watanabe and Komarck 1994, Baral 1996, Manca et al. 1998, Gurung et al. 2006, West Seti 2007, Thapa et al. 2010). However those of mid-land river in Pokhara valley probably have not yet been performed. The Seti Gandaki river, a snow-fed high altitude river flowing through the mid-land valley, in central Himalaya, Nepal, is a typical Himalayan lotic ecosystem with unique physiohydrological features such as high velocity, low to moderate temperature, unstable river-bed substrata etc. So, the present work aims to explore the diversity of phytoplankton of the Seti Gandaki river in Pokhara valley, Nepal.

\section{STUDY AREA}

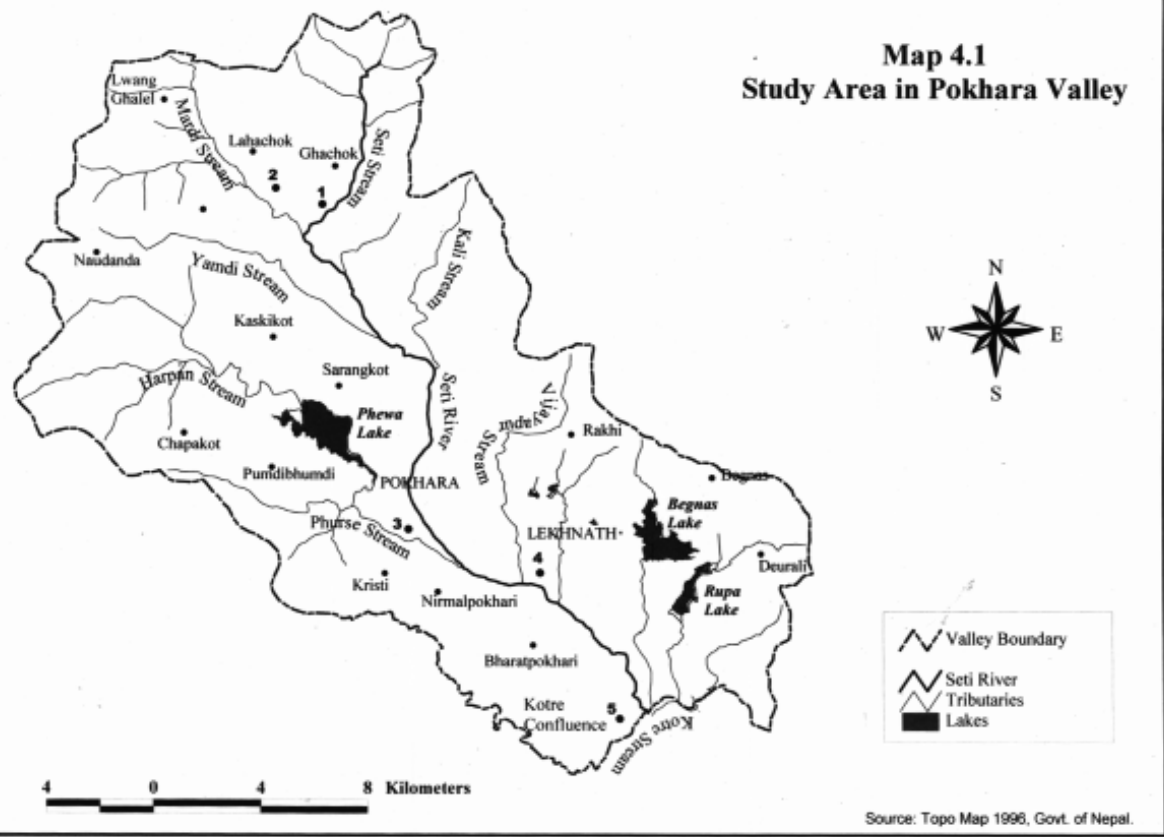

Figure 1. Study area in Pokhara Valley. 
Pokhara valley, known as "Nature's Paradise" in Western region of Nepal, has many fascinating water resources such as river, streams, brooks, lakes, ponds etc. It covers an area of about 200 sq $\mathrm{km}$, extending between $25^{\circ}$ and $07^{\prime}$ to $28^{\circ} 10^{\prime} \mathrm{N}$ latitude and $83^{\circ} 50^{\prime}$ to $84^{\circ} 50^{\prime} \mathrm{E}$ longitude and lies $800 \mathrm{~m}$ asl (Tripathi 1984-85). The lotic water bodies in Pokhara valley are the Seti Gandaki river and its tributaries. The river originates near the base of Mount Machhapuchhre (6997 $\mathrm{m}$ ) and Mount Annapurna (7529 m) flowing downwards receives several tributaries and passes through the heart of Pokhara valley (Fig. 1).

1). The study sites are situated at various places along the Seti Gandaki river on a stretch of about $30 \mathrm{~km}$ in and around Pokhara valley. Five sites were selected on the river which are as follows:

\section{Site 1. Lahachok}

The first site was a pre-urban site locating near the Lahachok village about $11.0 \mathrm{~km}$ upstream from the second site. The river banks on both sides were erosion sensitive and the watershed area had patchy forests, grasslands, agricultural fields and cremation spots. The river-bed had less sand and pebbles but with more stones and boulders.

\section{Site 2. Seti-Kali khola Confluence}

The second site was above the junction of Pokhara Sub-metropolitan city and Kanhu Village Development Committee (VDC), about $8.5 \mathrm{~km}$ from the third site. The watershed area had agricultural fields, some parts of Pokhara Sub-metropolitan city, villages, patchy forests, grasslands, cremation spots etc. The river-bed had more pebbles, stones and boulders but little sand.

\section{Site 3. Dobilla}

The third site was an urban site near Dobilla, the south-western point of Pokhara valley below the lower part of densly populated city area and about $4.5 \mathrm{~km}$ upstream from the fourth site. The watershed area had the villages, grasslands, agricultural fields, urban area and cremation spots. The river-bed had sand, pebbles, stones and boulders.

\section{Site 4. Seti-Vijayapur khola Confluence}

The fourth site was at the southern junction of Pokhara Sub-metropolitan city, Lekhnath Municipality and Nirmalpokhari VDC, about $5 \mathrm{~km}$ upstream from the fifth site. The watershed area had Government owned Livestock Development Farm, grasslands, patchy forests, agricultural fields, villages, cremation spots etc. The river-bed had more pebbles, stones and boulders but little sand.

\section{Site 5. Kotre}

The fifth site was near Kotre in Tanahun District (the district boundary between Kaski and Tanahun districts) about $20 \mathrm{~km}$ south-east from Pokhara city. The watershed area had agricultural fields, Lekhnath Municipality area, villages and cremation spots. The river-bed had sand, pebbles, stones and boulders.

\section{MATERIALS AND METHODS}

Present study was conducted during September 2003 and August 2004. The sampling of 
phytoplankton was done using a plankton net (30 cm diameter) made of bolting silk cloth (53 $\mathrm{m}$ mesh). Ten liters of water was poured through the net and plankton collected in a vial, which then was diluted in $20 \mathrm{ml}$ distilled water, kept in plankton vials, preserved in Lugol's solution and carried to the laboratory for further studies. Samples were collected monthly from each site and examined in a Sedgwick Rafter (S/R) cell under a compound microscope (15 ' 10x). The identification of the samples was done to the lowest possible taxonomic level following the reputed monographs/books of Smith (1950), Desikachary (1959), Edmondson (1959), Needham and Needham (1962), Prescott (1962) and APHA (1998).

\section{RESULTS AND DISCUSSION}

It work was explored the phytoplankton diversity of the Seti Gandaki river in Pokhara valley. Altogether 28 genera belonging to 19 families and 5 classes, viz., chlorophyceae, euglenophyceae, bacillariophyceae, dinophyceae and myxophyceae were recorded during the study period (Table 1).

Table 1. Diversity of phytoplankton in the Seti Gandaki river.

\begin{tabular}{|c|c|c|c|c|c|c|c|}
\hline \multirow[t]{2}{*}{ SN } & \multirow{2}{*}{ Classes/Families } & \multirow{2}{*}{ Genera } & \multicolumn{5}{|c|}{ Distribution sites } \\
\hline & & & 1 & 2 & 3 & 4 & 5 \\
\hline I & CHLOROPHYCEAE & & & & & & \\
\hline 1. & Chlamydomonadaceae & 01. Chlamydomonas Ehrenberg & - & + & - & - & - \\
\hline 2. & Ulotricaceae & 02. Ulothrix Kutzing & + & + & - & - & - \\
\hline 3. & Oedogoniaceae & 03. Oedogonium Link & - & + & - & - & - \\
\hline 4. & Senedesmaceae & 04. Scenedesmus Meyen & - & + & - & - & - \\
\hline \multirow[t]{2}{*}{5.} & \multirow[t]{2}{*}{ Zygnemataceae } & 05. Spirogyra Link & + & + & - & - & - \\
\hline & & 06. Zygnema Agardh & - & + & - & - & - \\
\hline II & EUGLENOPHYCEAE & & & & & & \\
\hline 1. & Euglenaceae & 07. Euglena Ehrenberg & - & + & - & - & - \\
\hline III & BACILLARIOPHYCEAE & & & & & & \\
\hline 1. & Tabellariaceae & 08. Tabellaria Ehrenberg & + & + & + & + & + \\
\hline 2. & Diatomaceae & 09. Diatoma De Candolle & + & + & - & - & + \\
\hline \multirow[t]{3}{*}{3.} & \multirow[t]{3}{*}{ Fragilariaceae } & 10. Fragilaria Lyngbye & - & + & - & - & - \\
\hline & & 11. Synedra Ehrenberg & + & + & - & + & + \\
\hline & & 12. Achnanthes Bory & + & + & + & + & + \\
\hline 4. & Achnanthaceae & 13. Cocconeis Ehrenberg & + & + & - & - & + \\
\hline
\end{tabular}




\begin{tabular}{|c|c|c|c|c|c|c|c|}
\hline 5. & Naviculaceae & 14. Navicula Bory & + & + & - & + & + \\
\hline 6. & Cymbellaceae & 15. Cymbella Agardh & + & + & + & + & + \\
\hline 7. & Nitzschiaceae & 16. Nitzschia Hassall & + & + & - & - & - \\
\hline IV & DINOPHYCEAE & & & & & & \\
\hline 1. & Gymnodiniaceae & 17. Gymnodinium Stein & - & + & - & - & - \\
\hline 2. & Peridiniaceae & 18. Peridinium Ehrenberg & + & + & - & + & - \\
\hline V & MYXOPHYCEAE & & & & & & \\
\hline \multirow[t]{2}{*}{1} & \multirow[t]{2}{*}{ Chroococaceae } & 19. Microcystis Kutzing & + & + & + & + & + \\
\hline & & 20. Merismopedia Meyen & - & + & - & - & - \\
\hline \multirow[t]{3}{*}{2.} & \multirow[t]{3}{*}{ Oscillatoriaceae } & 21. Phormidium Kutzing & + & + & - & + & + \\
\hline & & 22. Oscillatoria Vaucher & + & + & + & + & + \\
\hline & & 23. Schizothrix Kutzing & + & + & + & + & t \\
\hline \multirow[t]{3}{*}{3.} & \multirow[t]{3}{*}{ Nostocaceae } & 24. Anabaena Bory & + & + & + & + & + \\
\hline & & $\begin{array}{l}\text { 25. Anabaenopsis Woloszynska, } \\
\text { Miller }\end{array}$ & - & - & + & + & + \\
\hline & & 26. Nostoc Vaucher & + & + & - & - & + \\
\hline \multirow[t]{2}{*}{4.} & \multirow[t]{2}{*}{ Rivulariaceae } & 27. Rivularia Roth, Agardh & + & + & - & - & + \\
\hline & & 28. Gloeotrichia Agardh & + & - & - & - & - \\
\hline
\end{tabular}

1 = Lahachok, 2= Seti-Kali khola Confluence, $3=$ Dobilla, 4 = Seti-Vijaypur khola Confluence, $5=$ Kotre,$(+)=$ Present and $(-)=$ Absent.

Myxophyceae, bacillariophyceae and chlorophyceae comprising 10, 9 and 6 genera respectively were the predominant classes among the phytoplankters, followed by dinophyceae and euglenophyceae comprising 2 and 1 general respectively. Among myxophyceae, oscillatoriaceae and nostocaceae were found to be the dominant families comprising 3 genera each followed by chroococaceae and rivulariaceae, both having representation of 2 genera. Likewise, among bacillariophyceae, fragilariaceae and achnanthaceae were dominant families comprising of 2 genera each, followed by tabellariaceae, diatomaceae, naviculaceae, cymbellaceae and nitzschiaceae all having representation of single genus. Similarly, among the families of class Chlorophyceae, Zygnemataceae was the dominant family comprising 2 genera, followed by chlamydomonadaceae, ulotrichaceae, oedogoniaceae and scenedesmaceae, all representing single genus. The dominant genera were Microcystis, Oscillatoria and Anabaena; Tabellaria, Achnanthes and Cymbella; Ulothrix and Spirogyra; and Peridinium among myxophyceae, bacillariophyceae, chlorophyceae and dinophyceae respectively.

The genera occurring at all sites were Tabellaria, Achnanthes and Cymbella and Microcystis, 
Anabaena, Oscillatoria among bacillariophyceae and myxophyceae. But the genera recorded only from Site 2 (pre-urban site) were, Chlamydomonas, Oedogonium, Scenedesmus and Zygnema; Euglena; Fragilaria; Gymnodinium; and Merismopedia among chlorophyceae, euglenophyceae, bacillariophyceae, dinophyceae and myxophyceae respectively; Gloeotrichia only from Site 1 and none only from sites 3, 4 and 5 . The generic richness was highest (26 genera) and increased at Site 2 from Site 1 (19 genera), which abruptly declined at the urban site (Site 3) (9 genera), again increased at Site 4 (12 genera) and on increasing trend at downstream post-urban site (Site 5) (15 genera), most probably exhibiting the urban influence upon the riverine ecosystem and a longitudinal pattern of distribution.

The prominent human activities observed at the study sites were extraction of sand and stones, breaking of boulders from the river-bed and banks, movement of heavy vehicles for transportation of extracted materials, electro-fishing, release of toxic substances from the agricultural fields (using chemical fertilizers and pesticides near the waterbodies) and human settlements in the watershed area and direct disposal of urban wastes. The activities mentioned above probably influenced the abiotic and biotic components of the riverine ecosystem particularly at Site 3, having lowest generic richness, which reflects the perturbation of the aquatic environment due to urbanization and needs measures to control further deterioration.

Bacillariophyceae has been reported to be the predominant class among the phytoplankters in hill streams having natural environmental conditions, followed by myxophyceae, chlorophyceae, pyrrophyceae, euglenophyceae etc. Achananthaceae, naviculaceae, cymbellaceae and fragilariaceae among bacillariophyceae; chroococaceae, oscillatoriaceae and nostocaceae among myxophyceae and ulotricaceae and zygnemataceae among chlorophyceae were dominant representative families (Livingston et al. 1991, Gill et al. 1993, Joshi et al. 1996, Soylu and Gonulol 2003, West Seti 2007,Ganai et al. 2010, Thapa et al. 2010). Similar pattern of composition and dominance of various groups of phytoplanktors was observed in the present study, which could be attributed to the complex physiohydrological features and zoogeographical factors.

The taxa richness has markedly increased with decreasing altitude, increased from upstream site to downstream sites and a decline of both habitat stability and diversity at the urban sites which then returned to the increasing trend at the downstream post-urban sites (Srivastav et al. 1991, Ormerod et al. 1994). In the present study, the taxa richness was declined at the urban site which significantly inclined at the post-urban site, indicating the downstream increasing pattern, which could be due to the diverse physiography alongwith various abiotic and biotic factors including the human activities.

\section{ACKNOWLEDGEMENTS}

I am grateful to Prof. Dr. T.C. Majupuria, formerly Central Department of Zoology, Tribhuvan University and Prof. Dr. K. Basnet, Central Department of Zoology for their valuable suggestions and encouragement. I am grateful to the Institute of Science and Technology (IOST), Tribhuvan University for providing research grant for this study and to Prof. Dr. S.B. Karki, former, Central Department Zoology, T.U. for suggestions for sampling and preservation of samples. Associate Prof. P.J. Shah, Associate Prof. R.G. Dhewajoo, Head, Department of Zoology, Prithvi Narayan Campus, Tribhuvan University, Pokhara are acknowledged for providing the 
necessary laboratory facilities and valuable suggestions. I am thankful to Prof. S.J. Ormerod, Catchment Research Group, Cardiff University, U.K. and Prof. N.K. Mehra, Delhi University, India for their valuable suggestions.

Thanks are also due to Mr. B.R. Pahari, Senior Lab Boy, Department of Zoology, P.N.C. and Mr. N.P. Adhikari, Bhalam, Kaski for assistance in the laboratory and field works.

\section{REFERENCES}

Allan, J.D.,1995. Stream Ecology: Structure and function of running waters. Kluwer Academic Publishers, Dordrecht, The Netherlands, $388 \mathrm{p}$.

APHA,1998. Standard methods for the examination of water and wastewater. American Public Health Association (APHA), American Water Works Association (AWWA) and Water Environment Federation (WEF), Washington DC, USA, 10-157, pp I-49 (20th edition).

Baral, S.R.,1996. Diversity of blue-green algae (Cyanobacteria) in Nepal. In Jha, P.K., G.P.S. Ghimire, S.B. Karmacharya, S.R. Baral and P. Lacoul (eds) Environment and biodiversity: In the context of south Asia. Ecological Society (ECOS), Kathmandu, Nepal, pp 176-181.

Blum, J.L.,1954. Evidence for a diurnal pulse in stream phytoplankton. Science N. Y., 119: 732-734.

Brehm, V.,1911. Beobachtungen uber die Entstehung des potamoplanktons. International Review ges. Hydrobiology and Hydrography, 4:311-314.

Chakraborty, R.D., P. Ray and S.B. Singh,1959. A quantitative study of the plankton and physicochemical condition of the river Yamuna at Allahabad. Indian Journal of Fisheries, 6 (1):186-194.

Cushing, C.E.,1964. Plankton and water chemistry in the Montreal river lake-stream system, Saskatchewan. Ecology, 45:306-313.

Desikachary, T.V.,1959. Cyanophyta. Indian Council for Agricultural Research (ICAR), New Delhi, India, 686 p.

Edmondson, W.T.,1959. Fresh water biology. John Wiley and Sons, Inc., New York, 1248 p (2nd edition).

Ganai, A.H., P. Saltanat, A. A. Khan and H. Maryam, 2010. Phytoplankton diversity at Watlab Ghat in Wular lake, Kashmir. Journal of Ecology and the Natural Environment, 2(8):140-146.

Gill, S.K., S.K. Sahota, G.P.S. Sahota and H.S. Sahota,1993. Phytoplankton and physicochemical parameter examination of River Sutlej. Indian Journal of Environmental Protection, 13(3):171-175.

Gurung, T.B., R.P. Dhakal and J.D. Bista, 2006. Phytoplankton primary production, chlorophyll-a and nutrient concentrations in the water column of mountainous Lake Phewa, Nepal. Lakes and Reservoirs: Research and Management, 11(3):141-148.

Hirano, M.,1955. Fresh water algae. In Kihara, H. (ed) Flora and fauna of Nepal Himalaya. Kyoto University, Japan, pp 1-42.

Hynes, H.B.N.,1970. The ecology of running waters. Liverpool University Press, Liverpool, 555 p. 
Joshi A.R.,1977. Some myxophyceae of Kathmandu Valley, Nepal Oscillatoria. Journal of Natural History Museum, 1:89-92.

Joshi, B.D., R.C.S. Bisht, N. Joshi and R. Singh,1996. A study of planktonic and benthic components of three selected tributaries of river Ganga between Devprayag and Rishikesh. Himalayan Journal of Environment and Zoology, 10:23-26.

Kusel-Fetzmann, E.,1969. Einige algen aus Nepal. Khumbu Himal, 1:37-56.

Lauterborn, R.,1902. Beitrage zur mikrofauna und flora der Mosel. Z. Fisch., 9:1-25 (in German). Livinston, R.J., J.H. Epler, F. Jordan Jr., W.R. Karsteter, C.C. Koenig, A.K.S.K. Prasad and G.L. Ray,1991. Ecology of the choctawhatchee river system. In Livingston, R.J. (ed) The rivers of Florida. Springer-Verlag, New York, pp 247-274.

Mancas, M., D. Ruggin, P. Panzani, A. Asioli, G. Mura and A.N. Nocentini,1998. Report on a collection of aquatic organisms from high mountain lakes in the Khumbu valley (Nepalese Himalayas). Memoirs of Ist Italian Idrobiology, 57:77-98

Muller-Haeckel, A.,1966. Diatomeendrift im Fliessgewassern. Hydrobiologia, 28:73-87 (in German).

Needham, J.G. and P.R. Needham,1962. A Guide to the study of fresh water biology. HoldenDay Inc., San Francisco, 107 p.

Ormerod, S.J., S.D. Rundle, S.M. Wilkinson, G.P. Daly, K.M. Dale and I. Juttner,1994. Altitudinal trends in the diatoms, bryophytes, macroinvertebrates and fish of a Nepalese river system. Freshwater Biology, 32:309-322.

Prescott, G.W.,1962. Algae of the western great lakes area. WM.C. Brown Company Publishers, Dubuque, lowa, $965 \mathrm{p}$.

Reynolds, G.S. and J.P. Descy,1996. The production, biomass and structure of phytoplankton in large rivers. Arch. Hydrobiologia (Supplementary), 113:161-187.

Reynolds, C.S., J.P. Descy and J. Padisak,1994. Are phytoplankton dynamics in rivers so different from those in shallow lakes ? Hydrobiologia, 289:1-7.

Ruttner, F.,1956. Einige Beobachtungen uber das Verhalten des Planktons in Seeabflussen. Ost. Bot Z., 103: 98-109 (in German).

Ruttner, F.,1963. Fundamentals of limnology. Frey, D.G. and F.E.J. Fry (Translat.), University of Toronto Press, Toronto, $295 \mathrm{p}$.

Soballe, D.M. and B.L. Kimmel,1987. A large-scale comparison of factors influencing phytoplankton abundance in rivers, lakes and impoundments. Ecology, 68:1943-1954.

Soylu, E.N. and A. Gonulol, 2003. Phytoplankton and seasonal variation of the River Yeshirnak, Amasya, Turkey. Turkish Journal of Fisheries and Aquatic Sciences, 3:17-24.

Smith, G.M.,1950. The Fresh-water algae of the United States. McGraw Hill Book Company, Inc., New York, 719 p.

Srivastav, M., A.K. Srivastav and M.S.M. Rawat,1991. Physico-chemical and phycological 
assessment of the water of Ganga at Rishikesh and Hardwar. Recent researches in ecology, environment and pollution Volume 6. In Rajwar, G.S. (ed) Advances in Himalayan Ecology. Today and Tomorrow's Printers and Publishers, New Delhi, India, pp 255-265.

Thapa, S., P. B. Yonzon and A.K. Rai, 2010, Life of a river in the Himalaya: An ecological study of Trishuli river system in Nepal. Aquaculture Asia Magazine,15(1):37-40.

Tripathi, M.P.,1984-85. Ecology of Pokhara valley. In Majupuria, T.C. (ed) Nepal nature's paradise. White Lotus Co., Bangkok, Thailand, pp 438-452.

Watanabe, M. and J. Komarck,1994. Several cyanoprokaryotes from Sagarmatha National Park, Nepal Himalayas. Bulletin of National Science Museum,B. 20:1-29.

Welch, P.S.,1952. Limnology, Mc Graw-Hill Book Company, Inc., New York, 538 p.

West Seti Hydro Limited, 2007. Environmental assessment report: Environmental impact assessment. Project no.40919. Prepared by West Seti Hydro Limited, Kathmandu, Nepal for Asian Development Bank (ADB), 68 p.

Wetzel, R.G., 2001. Limnology. Academic Press, San Diego, USA, 1006 p (3rd edition).

Whitton, B.A.,1975. Algae. In Whitton, B.A. (ed) River ecology. Blackwell Scientific Publications, Oxford, pp 81-105.

\section{AUTHOR'S ADDRESS}

Kishor K. Pokharel

Department of Zoology

Prithvi Narayan Campus, Tribhuvan University, Pokhara, Nepal.

(email: kpokharel_3@hotmail.com) 